SHEs: Conference Series 3 (3) (2020) 1094- 1098

\title{
Improve Vocabulary Writing Skills through Image and Image Models on Indonesian Language Maples
}

\section{Desi Anggar Pratiwi}

SD Negeri Wukirsari

desyang1@gmail.com

\section{Article History}

accepted 14/11/2020

\begin{abstract}
The purpose of this study was to improve vocabulary writing skills in grade II SDN Wukirsari students through the application of the Picture and Picture model assisted by google meet. The research conducted was a Classroom Action Research (PTK) with three cycles, with each cycle consisting of two meetings. The stages of each cycle are planning, implementing, observing and reflecting. Each meeting is carried out a pre test and post test to determine the progress of students. In the first cycle students who completed after carrying out the post test were $50 \%$. In cycle II students who completed after carrying out the post test were $80 \%$. These results indicate that the Picture and Picture learning model can improve student learning outcomes, especially Indonesian language muples at SD Negeri Wukirsari.
\end{abstract}

Keywords: Writing vocabulary, picture and picture

\begin{abstract}
Abstrak
Tujuan penelitian ini adalah untuk meningkatkan keterampilan menulis kosa kata pada peserta didik kelas II SDN Wukirsari melalui penerapan model Picture and Picture dengan berbantuan google meet. Penelitian yang dilakukan adalah Penelitian Tindakan Kelas (PTK) sebanyak tiga siklus, dengan setiap siklusnya terdiri dari dua pertemuan. Tahapan setiap siklusnya adalah perencanaan, pelaksanaan, observasi dan refleksi. Setiap pertemuan dilakukan pre test dan post test untuk mengetahui perkembangan peserta didik. Pada siklus I peserta didik yang tuntas setelah melaksanakan post test sebesar $50 \%$. Pada siklus II peserta didik yang tuntas setelah melaksanakan post test sebesar $80 \%$. Hasil ini menunjukan bahwa model pembelajaran Picture and Picture dapat meningkatkan hasil belajar peserta didik khususnya mupel Bahasa Indonesia di SD Negeri Wukirsari
\end{abstract}

Kata kunci : Menulis kosa kata, picture and picture

Social, Humanities, and Education Studies (SHEs): Conference Series p-ISSN 2620-9284 https://jurnal.uns.ac.id/shes e-ISSN 2620-9292 


\section{PENDAHULUAN}

Ketika virus corona datang semua tatanan berubah begitupun terhadap dunia pendidikan. Pembelajaran tatap muka di sekolah dilarang diganti dengan pembelajaran dari rumah sesuai dengan Surat Edaran Nomor 4 Tahun 2020 Tentang Pelaksanaan Kebijakan Pada Masa Pandemi Belajar dari Rumah melalui pembelajaran daring/jarak jauh dilaksanakan untuk memberikan pengalaman belajar yang bermakna bagi peserta didik, tanpa terbebani tuntutan menuntaskan seluruh capaian kurikulum untuk kenaikan kelas maupun kelulusan. Masalah yang baru pun muncul, selain bagaimana melaksanakan pembelajaran jarak jauh tetapi juga bagimana cara guru tetap melakukan proses pembelajaran yang baik selama pandemi. Proses pembelajaran yang baik harus disesuaikan dengan karakteristik peserta didik agar peserta didik dapat menangkap materi yang diajarkan dengan baik. Pembelajaran yang dilakukan oleh guru juga harus kreatif dan tidak boleh monoton sehingga peserta didik tidak bosan. Penyampaian materi juga harus bervariasi agar peserta didik terdorong semangatnya sehingga aktif dan terus belajar. Guru tidak hanya berfokus pada penyampaian materinya tetapi juga harus memperhatikan perkembangan peserta didik yang terjadi di dalam proses pembelajaran.

Menurut Brunner dalam Sugandi (2007:36) ada empat hal pokok penting yang perlu diperhatikan yaitu peranan pengalaman struktur pengetahuan, kesiapan mempelajari sesuatu, intuisi dan cara membangkitkan motivasi belajar. Guru dituntut untuk bisa membawa peserta didik ke dalam dunia yang menyenangkan di dalam pembelajaran. Peserta didik yang merasa nyaman dan senang, maka akan berani untuk aktif dan akan mempunyai motivasi lebih untuk terus belajar. Peserta didik yang mempunyai motviasi lebih untuk belajar biasanya akan mendapatkan hasil belajar yang baik. Guru sebagai pemegang proses pembelajaran harus bisa menyajikan hal terbaik. Model pembelajaran yang digunakan haruslah sesuai dengan materi yang sedang diajarkan, karena tidak semua model pembelajaran dapat digunakan untuk semua materi. Pemilihan model pembelajaran akan mendukung hasil pembelajaran yang akan dicapai. Semua muatan pelajaran membutuhkan penerapan model pembelajaran.

Salah satu muatan pelajaran yang menuntut penggunaan model pembelajaran yang sesuai adalah muatan Pembelajaran Bahasa Indonesia merupakan salah satu pembelajaran yang wajib dilaksanakan pada pendidikan di Indonesia. Kurikulum 2013 menempatkan Bahasa Indonesia sebagai penghela mata pelajaran lain dan karenanya harus berada di depan semua mata pelajaran lain. Pembelajaran Bahasa Indonesia memiliki empat keterampilan berbahasa yang harus dimiliki siswa yaitu keterampilan mendengarkan, berbicara, membaca dan menulis (Dalman, 2012:3). Salah satu pelajaran yang dipelajari dalam Materi Bahasa Indonesia adalah menulis. Menulis merupakan salah satu keterampilan berbahasa yang dipergunakan dalam komunikasi secara tidak langsung. Keterampilan menulis tidak didapatkan secara alamiah, tetapi harus melalui proses belajar dan berlatih (Doyin dan Wagiran, 2009: 12). Ada berbagai macam jenis tulisan, salah satunya adalah menulis kosa kata. Menurut Soedjito (via Rahmawati, 2012: 1), kosakata atau perbendaharaan kata adalah semua kata yang terdapat dalam suatu bahasa. Diamond dan Gutlohn (2006) menyatakan bahwa: "Vocabulary is the knowledge of words and word meanings". Hal ini berarti bahwa kosakata merupakan pengetahuan tentang katakata dan arti kata. Dalam Kamus Bahasa Indonesia (Pusat Bahasa, 2008: 813), kosakata adalah perbendaharaan kata; vokabuler

Penggunaan model pembelajaran harus sesuai dengan materi yang disampaikan, jika tidak sesuai maka tujuan pembelajaran yang diiginkan tidak akan tercapai. Untuk meningkatkan menulis kosa kata juga akan rendah karena peserta didik tidak memahami materi pelajaran yang disampaikan. Kasus rendahnya pemahaman peserta didik mengenai materi Kosa kata pada mupel Bahasa indonesia masih banyak terjadi di SD di sekitar kita, seperti halnya di SD Negeri Wukirsari. Meningkatkan menulis kosa kata pada peserta didik kelas II masih rendah, hal ini dapat dilihat dari hasil Penilaian Pembelajaran 1 dimana hanya terdapat $50 \%$ peserta didik yang sudah dinyatakan tuntas dengan Kriteria 
Ketuntasan Minimum (KKM) sebesar 70. Ketuntasan belajar klasikal belum tercapai, yaitu sebesar $50 \%$ peserta didik memperoleh nilai di atas KKM.

Blachowicz dan Fisher (1996: 7) menyatakan bahwa "vocabulary learning takes place when students are active in discovering how words are related to experiences and to one another". Hal ini berarti bahwa pembelajaran kosakata dimulai ketika siswa aktif menemukan bagaimana kata-kata terhubung dengan pengalaman dan satu sama lain. Pengajaran yang baik adalah ketika para siswa secara aktif berusaha membangun makna sendiri. Banyak peneliti dalam bidang kosakata menyarankan bahwa membuat para siswa berperan aktif dalam membangun sebuah jaringan pemaknaan untuk sebuah kata merupakan hal yang penting. Pada Materi Kosa Kata pada Mupel Bahasa Indonesia pada penelitian ini menggunakan model pembelajaran Picture And Picture Model Picture And Picture adalah model pembelajaran yang menuntut partisipasi peserta didik untuk aktif dalam kegiatan pembelajaran. Peserta didik mengurutkan gambar-gambar menjadi urutan yang logis kemudian peserta didik mengemukakan alasan logis dari urutan gambargambar tersebut. Urutan gambar yang sudah tersusun digunakan peserta didik se-bagai dasar untuk menulis karangan (Suprijono, 2011: 125).

Langkah-langkah pembelajaran model Picture And Picture menurut Suprijono (2011: 125) adalah sebagai berikut: a. Guru menyampaikan kompetensi yang ingin dicapai. Kompetensi yang akan dicapai harus jelas agar memudahkan guru dalam menyampaikan pembelajaran serta sebagai alat untuk mengukur ketercapaian tujuan yang hendak dicapai;b. Menyampaikan materi sebagai pengantar. Sebelum memulai pelajaran, apersepsi sangat diperlukan bagi seorang guru dalam proses pembelajaran. Apersepsi tentunya berkaitan dengan kompetensi yang akan disampaikan;c. Guru memperlihatkan gambar-gambar kegiatan yang berkaitan dengan materi pelajaran. Media gambar dalam apersepsi membantu peserta didik dalam memahami konsep yang masih abstrak;d. Guru memanggil peserta didik secara bergantian mengurutkan gambar-gambar menjadi urutan yang logis;e. Guru menanyakan alasan pemikiran urutan gambar tersebut; $f$. Dari alasan gambar tersebut, guru menanamkan materi sesuai dengan kom-petensi yang ingin dicapai;g. Peserta didik menulis kosa kata berdasarkan urutan gambar;g. Peserta didik bersama guru membuat kesimpulan/rangkuman

\section{METODE}

Penelitian ini adalah penelitian tindakan kelas (Classroom Action Research) dengan menerapkan model pembelajaran Picture And Picture. Menurut Kurt Lewin dalam Kunandar (2011: 42) penelitian tindakan kelas ini terdiri dari empat tahapan dasar yaitu perencanaan (planning), pelaksanaan (acting), pengamatan (observing) dan refleksi (reflecting). Analisis penelitian ini adalah analisis deskriptif kuantitafif kualitatif dimana dalam penelitian ini selain penyajian hasil berupa data maupun angka peneliti juga menentukan bagaimana cara pengolahan hasil penelitian yakni dengan membuat analisisnya dengan menerapkan model penelitian Picture And Picture. Penelitian ini dilaksanakan pada peserta didik kelas II SD Negeri Wukirsari Tahun Pelajaran 2020/2021 selama dua siklus secara daring menggunakan aplikasi Google meet dengan dua pertemuan disetiap siklusnya. Siklus I dilaksanakan pada tanggal 12 dan 18 November 2020. Siklus II dilaksanakan pada tanggal 19 dan 25 November 2020. Teknik pengumpulan data yang dilakukan dengan observasi dan tes baik pre test maupun post test. Observasi meliputi observasi keterlaksanaan model pembelajaran Picture And Picture, sikap peserta didik dan keterampilan. Untuk hasil belajar menggunakan tes melalui Google form.

HASIL DAN PEMBAHASAN

Pada siklus I pembelajaran dilaksanakan selama dua pertemuan, setiap 1096 
pertemuan diadakan pre test dan post test. Untuk mengetahui perkembangan peserta didik selama pembelajaran. Siklus I membahas materi tentang kosa kata yang berhubungan dengan lingkungan sehat, berupa gambar - gambar lingkungan sehat dan tidak sehat dan. Pembelajaran dengan model Picture And Picture dilaksanakan dengan 6 langkah Picture And Picture secara berurutan mulai dari menentukan pertanyaan mendasar, merancang proyek, menyusun jadwal, memantau proses proyek, penilaian hasil dan evaluasi pengalaman. Proyek yang dibuat peserta didik adalah menulis kosa kata dengan melihat gambar yang tepat. Berikut ini adalah hasil belajar peserta didik pada siklus I yang bisa dilihat pada tabel berikut.

Tabel 1. Hasil Belajar Peserta Didik Siklus I

\begin{tabular}{lcccccccc}
\hline \multirow{2}{*}{ Siklus I } & \multicolumn{3}{c}{ Pre test } & $\begin{array}{c}\text { Pesdik } \\
\text { tuntas }\end{array}$ & $\begin{array}{c}\text { Pesdik belum } \\
\text { tuntas }\end{array}$ & $\begin{array}{l}\text { Pesdi } \\
\mathbf{k} \\
\text { tunta } \\
\mathbf{s}\end{array}$ & $\begin{array}{c}\text { Post test } \\
\text { Pesdik } \\
\text { tuntas }\end{array}$ & belum \\
& Jml & $\%$ & Jml & $\%$ & Jml & $\%$ & Jml & $\%$ \\
\hline Pertemuan 1 & 1 & 16 & 5 & 83 & 2 & 33 & 4 & 66 \\
\hline Pertemuan 2 & 2 & 66 & 4 & 33 & 3 & 50 & 3 & 50 \\
\hline
\end{tabular}

Berdasarkan tabel di atas maka terjadi peningkatan antara pre test dan post test pada pertemuan 1. Setiap individu peserta didik masih belum mengalami peningkatan hasil belajarnya. Peserta pada pertemuan 1, 2 anak mencapai ketuntasan. Ketuntasan klasikal mengalami peningkatan, pada pre test hanya terdapat anak yang sudah tuntas, tetapi pada post test bertambah menjadi 2 anak yang sudah tuntas dengan Kriteria Ketuntasan Minimal (KKM) sebesar 75. Demikian juga pada pertemuan 2 jumlah peserta didik yang sudah tuntas KKM mengalami peningkatan. Pada pre test ada 2 anak yang baru tuntas, sudah meningkat menjadi 3 peserta didik yang tuntas setelah melaksanakan post test. Perbandingan antara hasil post test pada pertemuan 1 dan pertemuan 2 juga terdapat perbedaan. Pada pertemuan 1 peserta didik yang sudah tuntas hanya ada 2 anak, sedangkan pada pertemuan 2 sudah meningkat menjadi 3 anak. Persentase ketuntasan klasikalnya meningkat, jika pertemuan 1 hanya $33 \%$ maka pada pertemuan 2 menjadi 50\%.

Berdasarkan refleksi pada siklus I maka diputuskan untuk melanjutkan ke siklus II dikarenakan belum mencapai ketuntasan klasikal yang diharapkan. Siklus II membahas materi kosa kata yang berhubungan dengan jalan raya. Pembelajaran dengan model Picture And Picture dilaksanakan dengan 6 langkah Picture And Picture secara berurutan seperti siklus I Proyek yang dibuat peserta didik adalah gambar yang berhubungan dengan jalan raya secara tepat. Berikut ini adalah hasil belajar peserta didik pada siklus II yang bisa dilihat pada tabel berikut.

Tabel 2. Hasil Belajar Peserta Didik Siklus II

\begin{tabular}{|c|c|c|c|c|c|c|c|c|}
\hline \multirow{3}{*}{ Siklus II } & \multicolumn{4}{|c|}{ Pre test } & \multicolumn{4}{|c|}{ Post test } \\
\hline & & & $\begin{array}{r}\text { Pesd } \\
\text { tu }\end{array}$ & $\begin{array}{l}\text { belum } \\
\text { is }\end{array}$ & tu & & $\begin{array}{l}\text { Pesdik } \\
\text { tuntas }\end{array}$ & belum \\
\hline & Jml & $\%$ & Jml & $\%$ & Jml & $\%$ & $\mathrm{Jml}$ & $\%$ \\
\hline Pertemuan 1 & 3 & 50 & 3 & 50 & 4 & 66 & 2 & 33 \\
\hline Pertemuan 2 & 4 & 66 & 2 & 33 & 5 & 83 & 1 & 16 \\
\hline
\end{tabular}


Berdasarkan tabel di atas maka terjadi peningkatan antara pre test dan post test pada pertemuan 1. Setiap individu peserta didik sudah mengalami peningkatan hasil belajarnya. Ketuntasan klasikal juga mengalami peningkatan, pada pre test hanya terdapat 3 anak yang sudah tuntas, tetapi pada post test bertambah menjadi 4 anak yang sudah tuntas dengan Kriteria Ketuntasan Minimal (KKM) sebesar 75. Demikian juga pada pertemuan 2 jumlah peserta didik yang sudah tuntas KKM mengalami peningkatan. Pada pre test ada 4 anak yang baru tuntas, sudah meningkat menjadi 5 peserta didik yang tuntas setelah melaksanakan post test. Perbandingan antara hasil post test pada pertemuan 1 dan pertemuan 2 juga terdapat perbedaan. Pada pertemuan 1 peserta didik yang sudah tuntas hanya ada 4 anak, sedangkan pada pertemuan 2 sudah meningkat menjadi 5 anak. Persentase ketuntasan klasikalnya meningkat, jika pertemuan 1 hanya $66 \%$ maka pada pertemuan 2 menjadi $83 \%$.

Dari dua siklus yang sudah dilaksanakan selama 4 pertemuan dapat dipastikan bahwa model pembelajaran Picture And Picture dapat meningkatkan menulis kosa kata pada mupel bahasa Indonesia Kelas II di SD Negeri Wukirsari. Hal ini sesuai dengan konsep atau teori yang dikemukakan oleh Suprijono, bahwa Model Picture And Picture didasari oleh teori belajar konstruktivisme. Teori konstruktivisme mengemukakan bahwa belajar adalah menemukan sendiri dan mentransformasikan informasi kompleks, guru memberikan kemudahan kepada peserta didik untuk mem-bangun pengetahuannya sendiri.

\section{SIMPULAN}

Penerapan model pembelajaran Picture And Picture dapat meningkatkan keterampilan menulis peserta didik Kelas II pada mupel Bahasa Indonesia materi kosa kata. Peningkatan yang terjadi karena adanya kesan pembelajaran yang mendalam dari peserta didik tehadap materi yang diajarkan melalui setiap gambar yang dibuat. Peserta didik akan selalu teringat akan materi yang diajarkan dikarenakan mereka menemukan dan membangun sendiri pengetahuan mereka pada saat membuat gambar. Berdasarkan penelitian yang telah dilaksanakan salah satu model pembelajaran yang harus dikuasai guru adalah Picture And Picture karena model ini sangat cocok digunakan dalam keadaan pandemi seperti ini, apalagi dalam kondisi belajar dari rumah. Peserta didik akan membangun pengetahuannya sendiri dengan gambar - gambar. Guru bisa memantau proses selama proyek dilaksanakan dengan bekerja sama denagn orang tua.

\section{DAFTAR PUSTAKA}

Blachowicz dan Fisher (1996). Kosa kata dalam Bahasa Indonesia Jakarta: PT Raja Grafindo Persada.

Gutlohn, Diamond (2006). Keterampilan Dasar Menulis. Jakarta: Universitas Terbuka

Hanafiah, dan Cucu Suhana. (2009). Konsep Strategi Pembelajaran. Bandung: PT Refika aditama

Rahmawati, Soedjito (2012). Kosakata atau perbendaharaan kata Kamus Bahasa Indonesia. Jakarta (Pusat Bahasa, 2008: 692),

Sudjana, N. (2009). Penilaian Hasil Proses Belajar Mengajar (Cetakan Ketigabelas). Bandung: PT Remaja Rosdakarya.

Sugandi, A. 2007. Teori Pembelajaran. Semarang: UNNES Press.

Syarif, Erlina, dkk. (2009). Pembelajaran Menulis. Jakarta: Departemen Pendidikan Nasional Direktorat Jendral Peningkatan Mutu Pendidikan dan Tenaga Kependidikan Pusat Pengembangan dan Pemberdayaan Pendidikan dan Tenaga Kependidikan Bahasa

Suprijono. (2011). Penerapan Model Picture And Picture untuk Meningkatkan Kecermatan dan Kreasi Seni Rupa. DIADIK : Jurnal IImiah Teknologi Pendidikan, 7(2).

Tarigan, Henry Guntur. (2008). Menulis Sebagai Suatu Keterampilan Berbahasa. Bandung: Angka 
SHEs: Conference Series 3 (3) (2020) 1094- 1098

(c) (i) (2) This work is licensed under a Creative Commons Attribution-ShareAlike 4.0 International License. 